\title{
CASE MANAGER AND ITS ROLE IN SUPPORTING PATIENT CENTERED CARE AT PKU MUHAMMADIYAH HOSPITAL, YOGYAKARTA
}

\author{
Widarti \\ Masters Program in Hospital Management, Faculty of Health Sciences, \\ Universitas Muhammadiyah Yogyakarta
}

\begin{abstract}
Background: Nowadays, patient care paradigm is a patient-focused service or Patient Centered Care (PCC). Case manager has an important role in the intervention to improve quality, control costs, patient safety, integrated care, and maintain service and patient satisfaction. This study aimed to investigate case manager and its role in supporting patient centered care at PKU Muhammadiyah Hospital, Yogyakarta.

Subjects and Method: A qualitative study with a phenomenological approach was conducted at PKU Muhammadiyah Hospital, Yogyakarta, Indonesia. A total of 30 key informants were selected for this study, including case managers, service supervisors, and supporters in hospitals. The data were obtained using in-depth interview and Focus Group Discussion (FGD).

Results: The case manager's role had been to support the implementation of PCC at PKU Muhammadiyah Yogyakarta Hospital. The implementation was manifested by the appointment of 2 case managers, namely doctor and nurse through a director's decree. The roles that case managers play in supporting PCC were coordination, communication, supervision, prevention, and plan for patient care. The role had not been optimally carried out because it was constrained by multi-role barrier, ethical legal, and incomplete introduction.

Conclusion: Case manager at PKU Muhammadiyah Hospital in Yogyakarta has supported the implementation of PCC. The main roles performed are communication and coordination.
\end{abstract}

Keywords: case manager, patient centered care

\section{Correspondence:}

Widarti. Masters Program in Hospital Management, Faculty of Health Sciences, Universitas Muhammadiyah Yogyakarta. Email: buwidarti@yahoo.co.id. Mobile: o81328041542.

The $6^{\text {th }}$ International Conference on Public Health

Best Western Premier Hotel, Solo, Indonesia, October 23-24, 2019 | 287

https://doi.org/10.26911/the6thicph.04.49 